\title{
Pelatihan Pembuatan Video Pembelajaran Dengan Aplikasi Bandicam dan Screencast O-Matic
}

\author{
Ofirenty Elyada Nubatonis \\ Program Studi Pendidikan Matematika FKIP Universitas Nusa Cendana \\ ofirenty@Staf.undana.ac.id
}

\begin{abstract}
The problem faced by teachers in East Nusa Tenggara is the limited use of technology in producing instructional media or digital audio-visual teaching materials. The impact of this limitation was most felt during the Covid-19 pandemic, online learning did not work effectively. Finally, the Network learning process is carried out which happens to the extent that the teacher sends the assignment and the students do the given assignment and then sent it back via the messenger application. When the teacher sends teaching materials in the form of instructional videos to explain certain concepts, most of the videos are taken from the internet and are not written by themselves. Therefore, it is necessary to hold training in making learning videos using applications that are easy to master, do not require money, and simply use a laptop. In this activity, teachers are provided with the knowledge and practice of making instructional videos using the Bandicam and Screencast O-Matic applications. The form of this activity is online training. The methods used are seminars, lectures, discussions, and mentoring. The results of this activity were 1) increased teacher knowledge about the use of the Bandicam and Screencast O-Matic applications in making instructional videos, 2) teachers were able to develop instructional videos using Bandicam and Screencast O-Matic
\end{abstract}

Key Word : Bandicam, Learning, Training, Development, Screencast O-Matic, Video

Sitasi

Nubatonis, Ofirenty Elyada. (2021). Pelatihan pembuatan video pembelajaran dengan aplikasi bandicam dan screencast o-matic. Jurnal Nasional Pengabdian Masyarakat, 2(1). 11-20.

\section{Pendahuluan}

Dalam merancang dan mempersiapkan proses pembelajaran melibatkan banyak komponen dan aktivitas yang harus terencana dengan baik, sistematis dan terukur. Perencanaan dan perancangan proses pembelajaran dilakukan oleh guru dengan mempersiapkan perangkat pembelajaran yang terdiri dari RPP, bahan ajar, media pembelajaran, dan instrument penilaian. Seiring dengan perkembangan teknologi dan informasi, penggunaan teknologi sebagai salah inovasi untuk mengembangkan bahan pembelajaran yang kreatif dan inovatif sangat diperlukan dalam memudahkan siswa belajar tanpa dibatasi oleh ruang dan waktu. Siswa dapat merasakan kemudahan dalam mengakses materi pembelajaran bahkan mengikuti proses pembelajaran tanpa dibatasi oleh ruang dan waktu.

Apalagi data mencatat bahwa sebagian anggota masyarakat remaja setiap saat tidak terpisahkan dari media digital yang menjadi tanda bahwa masyrakat kita berada pada masa revolusi digital dan berpengaruh pada motivasi belajar siswa (Muhasim, 2017). Menurut Salsabila, dkk (2020) penggunaan teknologi dan jaringan internet menjadi salah satu 
jembatan komunikasi yang efektif antara guru dan siswa mengakibatkan penyampaian informasi menjadi lebih cepat dan efektif dan efisien. Terlepas dari kondisi global yang terjadi saat ini yakni pandemic Covid-19 yang belum kunjung selesai sejak tahun 2019, selain kegiatan tatap muka di kelas, guru juga perlu mengembangkan perangkat pembelajaran atau bahan pembelajaran dalam jaringan yang dapat membantu siswa belajar mandiri di rumah, mengulang kembali setiap materi yang diajarkan oleh guru, mengerjakan tugas tanpa dibebani dengan penggunaan kertas yang berlebihan dan bisa menghasilkan sampah bagi lingkungan, serta masih banyak lagi kemudahan yang dapat diperoleh siswa. Hal ini akan berjalan dengan baik bila guru menguasai penggunaan berbagai teknologi yang menunjang proses pembelajaran. Guru-guru banyak mengalami kendala dalam menguasai teknologi pembelajaran.

Berdasarkan hasil wawancara dan observasi di lapangan, guru-guru di propinsi Nusa Tenggara Timur mengalami masalah dalam memanfaatkan teknologi untuk mengembangkan pembelajaran dalam jaringan. Dampak dari permasalahan ini sangat dirasakan ketika virus Covid -19 mewabah di NTT dan kegiatan tatap muka di kelas ditiadakan dan harus diganti dengan tatap muka secara daring. Lebih jauh lagi, pembelajaran menjadi tidak efektif dan efisien. Tidak semua materi pembelajaran tersampaikan dengan baik karena guru menggunakan aplikasi yang fungsinya terbatas. Guru-guru hanya mengirimkan materi dalam bentuk pdf atau sejenisnya untuk dibaca dan dipelajari oleh siswa lalu diberikan latihan soal untuk menguji pemahaman siswa. Bahkan ada juga yang hanya mengirimkan tugas-tugas yang harus dikerjakan pada buku sumber yang diberikan. Sementara banyak materi yang tidak bisa dipahami oleh siswa secara mandiri dan siswa butuh bimbingan guru dalam memahami materi tersebut. Ada juga guru menggunakan video pembelajaran yang tersedia di internet. Namun terkadang video-video yang digunakan tidak sesuai dengan keadaan lingkungan social budaya serta kemampuan siswa. Akibatnya kompetensi atau tujuan dari proses pembelajaran tidak tercapai dengan baik. Akibat jangka panjangnya, siswa akan mengalami kesulitan ketika akan mempelajari materi-materi yang di jenjang pendidikan yang lebih tinggi.

Mengatasi permasalah yang dialami di atas, maka tim pengabdian masyarakat Program Studi Pendidikan Matematika FKIP Universitas Nusa Cendana mengadakan pelatihan bagi guruguru di Nusa Tenggara Timur. Pelatihan yang dibuat adalah pelatihan merancang video pembelajaran sebagai bahan ajar audio visual atau media pembelajaran audio visual dengan menggunakan aplikasi Bandicam dan Screen O-Matic. Luaran yang diharapkan dari kegiatan ini adalah guru-guru mampu mengembangkan video pembelajaran dengan dengan menggunakan aplikasi Bandicam atau Screen O-Matic atau kedua-duanya. Lebih lanjut, video ini akan diupload dalam akun youtube masing-masing lalu digunakan dalam pembelajaran dalam jaringan di kelas masing-masing.

Menurut Herayanti, dkk (2019), bandicam menjadi salah satu alat perekam layar yang dipilih karena memiliki kelebihan seperti proses instalasi yang mudah, dapat disetting format video yang ingin dihasilkan dalam format MP4 atau AVI, resolusi dapat disesuaikan dengan laptop dan dapat menampilkan wajah pemateri dengan mengatifkan webcam. Sebagaimana Bandicam, Screen O-Matic juga menawarkan fitur-fitur dan kemudahan yang sama sebagai aplikasi perekam layar (Marlena, dkk, 2018).

\section{Metode Pelaksanaan}

Bentuk kegiatan pengabdian ini adalah pelatihan dalam jaringan. Metode yang digunakan adalah seminar sehari, diskusi, Tanya jawab dan pendampingan pembuatan video pembelajaran. Jumlah peserta yang hadir dalam kegiatan adalah 90 peserta. Peserta dari 
kegiatan ini adalah guru-guru yang berasal dari berbagai daerah di Nusa Tenggara Timur.

Kegiatan ini dilaksanakan dalam 3 tahapan yaitu:

a. Persiapan. Kegiatan pengabdian adalah kegiatan dalam jaringan sehingga dapat menjangkau guru-guru yang tersebar diseluruh wilayah Nusa Tenggara Timur. Informasi tentang kegiatan ini disebarkan menggunakan brosur dengan memanfaatkan media sosial seperti facebook, WhatsApp Grup, Grup telegram dan lain-lain. Kegiatan pendaftran dibuka sejak satu bulan sebelum kegiatan dimulai. Pendaftran dilakukan secara online dengan mengisi Google Form.

b. Pelatihan Pembuatan Video Pembelajaran dengan Menggunakan Aplikasi Bandicam dan Screen O-Matic

Kegiatan ini dilaksanakan secara daring dengan menggunakan aplikasi zoom dan siaran langsung melalui youtube. Pelatihan yang diberikan dalam bentuk ceramah interaktif dari pemateri. Pemateri memberikan penjelasan tentang penggunaan aplikasi Bandicam dan Screen O-matic. Media yang digunakan adalah media powerpoint serta memberi simulasi tentang penggunaan kedua aplikasi tersebut. Setelah mendengarkan materi dari tim pengabdian, peserta diberi kesempatan untuk bertanya dan berdiskusi terkait dengan penggunaan aplikasi serta proses pembuatan video pembelajaran yang kreatif, inovatif dan menarik. Tindak lanjut dari kegiatan ini, pendampingan bagi guru-guru dalam merancang atau mengembangkan video pembelajaran.

c. Pendampingan Pembuatan Video Pembelajaran dengan Menggunakan Aplikasi Bandicam dan Screen O-Matic.

Pendampingan pembuatan video pembelajaran ini dilaksanakan selama 2 minggu. Guruguru diberi kesempatan membuat video pembelajaran selama satu minggu. Video yang telah dibuat dikonsultasikan dan direvisi berdasarkan catatan-catatan dari tim pengabdian. Video yang telah direvisi dapat diupload di channel youtube masing-masing dan digunakan untuk pembelajaran daring di kelas.

\section{Hasil Pelaksanaan dan Diskusi}

a. Pelatihan Pembuatan Video Pembelajaran Menggunakan Aplikasi Bandicam dan Screen O-Matic

Pelatihan ini dilaksanakan pada hari Kamis tanggal 06 Mei 2021. Kegiatan ini bertujuan membekali peserta dengan pengetahuan dasar tentang pembuatan video pembelajaran, perancangan media presentasi yang menarik, pengetahuan dasar tentang aplikasi Bandicam dan Screen O-Matic serta simulasi pembuatan video pembelajaran menggunakan aplikasi Bandicam dan Screen O-Matic. Pemberian materi ditujukan agar guru-guru memiliki pengetahuan yang mendalam tentang pembuatan video pembelajaran dengan menggunakan aplikasi Bandicam atau Screen O-matic atau kedua-duanya. Pengetahuan yang diberikan dijadikan dasar atau pedoman saat pengembangan video pembelajaran sesuai dengan bidang ilmu masing-masing.
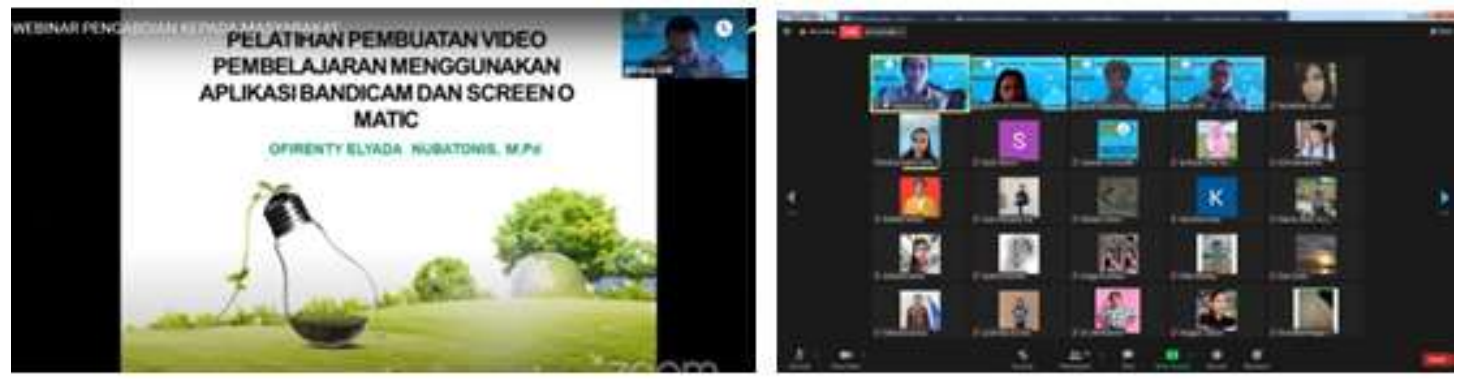

Gambar 3.1. Pelatihan Pembuatan Video Pembelajaran secara Daring 
Dalam kegiatan ini pemateri memberikan ceramah tentang langkah-langkah pembuatan video pembelajaran yaitu menentukan konsep video, membuat materi presentasi dalam bentuk power point yang kreatif, mempersiapkan alat-alat yang dibutuhkan, pembuatan video, evaluasi terhadap video, editing dan publikasi. Materi ini diberikan untuk memberikan gambaran kepada peserta tentang tahapan-tahapan yang akan dilalui saat pembuatan video pembelajaran nanti. Selain itu, peserta juga dibekali dengan simulasi penggunaan aplikasi Bandicam dan Screen O-Matic.

Dalam membekali peserta tentang penggunaan aplikasi Bandicam dan Screen O-matic, peserta diperkenalkan terlebih dahulu tentang fitur-fitur yang ada pada kedua aplikasi tersebut serta pengaturan-pengaturan yang perlu dilakukan agar menghasilkan video pembelajaran yang berkualitas. Selanjutnya, peserta dibekali dengan simulasi pembuatan video pembelajaran menggunakan aplikasi Bandicam maupun Screen O-Matic. Pemateri juga memaparkan tentang kelemahan dan kelebihan dari masing-masing aplikasi sebagai saran bagi peserta dalam menentukan pilihan untuk menggunakan aplikasi tersebut.

Setelah pemaparan materi tersebut kegiatan dilanjutkan dengan diskusi dan tanya jawab. Dalam kegiatan ini peserta dengan antusias mengikuti mendengarkan materi, berdiskusi dan memberi komentar-komentar positif terkait dengan materi yang diberikan. Peserta dibekali dengan pengetahuan yang baru dalam rangka meningkatkan kualitas pembelajaran di kelas.

Harapan dari peserta agar dilaksanakan kegiatan-kegiatan pelatihan terkait dengan penggunaan teknologi seperti pengembangan pembelajaran berbasis E-Learning, pembuatan media pembelajaran matematika interkatif menggunakan berbagai aplikasi, dan pelatihan tentang pembelajaran matematika dengan metode blended learning.
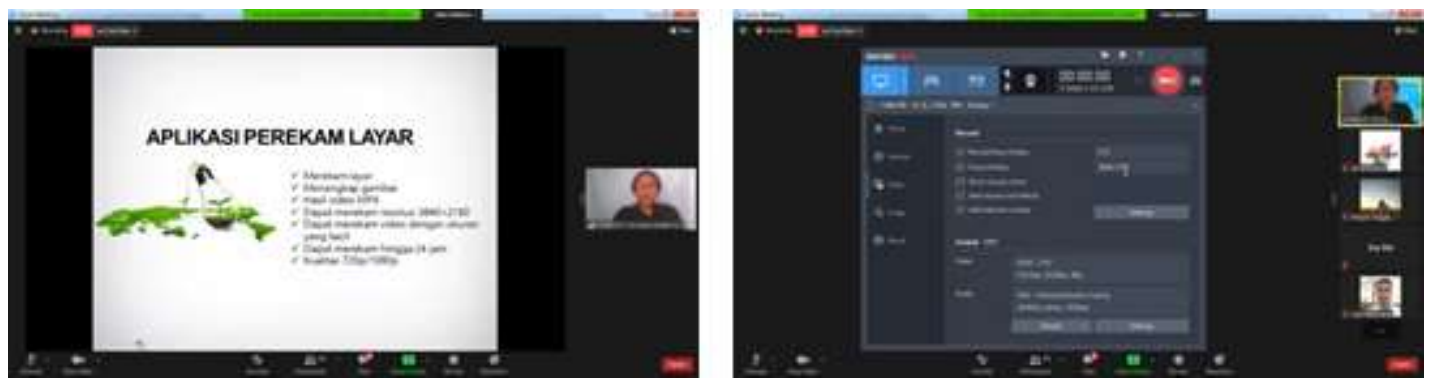

Gambar 3.2. Pemberian Materi tentang Aplikasi Bandicam dan Screen O-Matic

\section{b. Pendampingan Pembuatan Video Pembelajaran dengan Menggunakan Aplikasi} Bandicam dan Screen O-Matic

Pendampingan pembuatan video pembelajaran sebagai bagian dari kegiatan pengabdian masyarakat ini dilaksanakan selama 2 minggu yakni dari tanggal 7 Mei 2021 sampai dengan 23 Mei 2021. Peserta yang mengikuti kegiatan ini sebanyak 53 orang. Adapun tahapan-tahapan kegiatan pendampingan ini adalah :

1) Menentukan konsep/tema dari video pembelajaran. Peserta diminta memilih satu Kompetensi Dasar pada mata pelajaran yang diasuh. Peserta merumuskan indikator dan tujuan pembelajaran. Peserta berkonsultasi lewat grup WhatsApp yang dibuat. Dalam kegiatan ini ditemukan 31 peserta $(58,48 \%)$ dapat merumuskan Indikator Pencapaian Kompetensi (IPK) dengan benar dan 22 peserta belum dapat merumuskan IPK dengan baik. Peserta yang telah merumuskan indikator pencapaian kompetensi dengan benar dapat melanjutkan ke aktifitas berikut. Sementara peserta yang belum 
bisa merumuskan indikator pencapaian kompetensi dan tujuan pembelajaran dengan baik diminta untuk memperbaiki rumusan IPK dan tujuan pembelajaran.

Kesulitan-kesulitan yang dialami peserta dalam merumuskan IPK sesuai dengan kompetensi dasar yang dipilih antaralain 1) Peserta mengalami kesulitan dalam memilih kata kerja operasional yang tepat, 2) Peserta sulit menentukan aktifitas belajar yang dapat terukur, dan 3) Peserta tidak dapat menentukan urutan materi yang harus diajarkan. Ketika peserta mengalami kesulitan dalam merumuskan indikator pencapain kompetensi maka tujuan pembelajaran yang dirumuskan juga masih belum tepat. Dalam merumuskan tujuan pembelajaran ditemukan bahwa masih ada peserta merumuskan tujuan pembelajaran yang tidak sesuai dengan indikator pencapaian kompetensi dan juga peserta sulit merumuskan tujuan pembelajaran dengan memperhatikan audiens, kompetensi/kemampuan yang ingin dicapai, keaadaan serta derajat pengukuran.

Peneliti menemukan bahwa kesulitan dalam menentukan indikator pencapaian kompetensi serta tujuan pembelajaran disebabkan karena kurangnya pengetahuan peserta tentang komponen-komponen kurikulum 2013 dan penguasaan materi/konsep yang rendah. Temuan dalam kegiatan ini sejalan dengan hasil penelitian yang dilakukan oleh Palobo dan Tembang (2019), yakni, guru sulit menentukan kata operasional yang tepat serta guru sulit menentukan kepentingan indikator sebagai indikator penting atau hanya sebagai penunjang. Selanjutnya, Palobo dan Tembang (2019) juga mengemukakan bahwa dalam kurikulum 2013, Indikator Pencapaian Kompetensi tidak ditentukan oleh pemerintah sehingga guru mengembangkan IPK sesuai kompetensi dasar secara mandiri. Dalam menentukan IPK guru perlu memperhatikan metode/strategi pembelajaran, memperhatikan materi ajar, mempertimbangkan karakter siswa yang didukung oleh sumber daya di sekolah.

2) Merancang media presentasi powerpoint. Peserta diminta merancang media animasi atau media presentasi powerpoint. Media animasi atau media presentasi yang dihasilkan ini akan digunakan sebagai media/alat untuk membantu guru membuat video pembelajaran yang berfungsi sebagai bahan ajar audio-visual atau media pembelajaran interaktif.

Dalam kegiatan ini semua peserta sudah mengenal dan dapat menggunakan media powerpoint dengan baik walaupun masih terdapat peserta yang kurang memperhatikan seni artistik/tampilan dari media presentasi seperti keserasian pemilihan warna, ukuran huruf, waktu animasi dan penggunaan gambar-gambar yang tidak sesuai dengan tema presentasi/media pembelajaran. Menurut Jones (2003), hal ini dikarenakan media ini sangat mudah digunakan dan menjadi alternatif yang lebih sedikit fleksibel untuk menggantikan penyajian materi cara lama (menggunakan kapur tulis dan papan).

Terlepas dari kemudahan penggunaan, dalam menyusun konten-konten materi/konsep dalam media presentasi ini yang masih menjadi kendala bagi beberapa peserta. Peserta mengalami kesulitan menentukan urutan materi, metode pembelajaran dan urutan kegiatan pembelajaran. Selain media presentasi dengan powerpoint sebagai aplikasi yang dilengkapi dengan animasi, pilihan-pilhan warna dan tampilan menarik, dapat merekam suara, menyajikan gambar, dan video-video perlu diperhatikan pula konten yang akan dimuat dalam presentasi yang dibuat. Apalagi ketika media powerpoint dipakai dalam proses pembelajaran maka penguasaan materi/konten pembelajaran menjadi faktor utama keberhasilan penggunaan media ini. Guru dituntun mampu menyajikan konsep/materi dengan urutan yang baik, sistematis, 
sesuai dengan karakteristik dan kemampuan siswa, serta urutan-urutan kegiatan presentasi mengutamakan aktifitas penemuan terbimbing sehingga presentasi guru tidak menjadi kegiatan ceramah yang membosankan siswa. Urutan materi disusun dalam point-point penting agar presentasi tidak meluas dan mengaburkan konsep yang ingin diajarkan (Jones, 2003). Hal ini sejalan dengan penelitian yang dilakukan Hadiyanti dan Widya (2018) bahwa presentasi guru dengan dipengaruhi oleh keterampilan guru menyajikan animasi, keterampilan memanfaatkan contoh dan gambar yang menarik, keterampilan memanfaatkan ilustrasi untuk memperjelas materi yang kompleks dan penyajian yang sistematis yang menyederhanakan konsep. Pada akhirnya aplikasi ini dapat bermanfaat sebagai teknologi yang tepat guna dalam kegiatan belajar mengajar dikelas dan sebagai salah satu cara baru guru dalam mengajar untuk meningkatkan motivasi belajar siswa dikelas (Shigli, dkk, 2016) dan media presentasi powerpoint menjadi alat pedagogis yang ampuh dalam proses pembelajaran (Lari, 2014).

3) Membuat video pembelajaran menggunakan aplikasi Bandicam dan Screen O-Matic Dalam kegiatan ini peserta diminta membuat video pembelajaran dengan bantuan media presentasi powerpoint yang telah disiapkan sebelumnya. Peserta diminta mencoba menggunakan salah satu aplikasi yang disukai atau bisa juga mencoba menggunakan kedua aplikasi tersebut. Dari 53 peserta terdapat 47 peserta $(88,68 \%)$ yang hanya menggunakan Bandicam saja, 3 peserta $(5,66 \%)$ yang menggunakan Screen O-Matic saja dan 3 orang peserta $(5,66 \%)$ yang mencoba menggunakan kedua aplikasi tersebut. Berdasarkan hasil wawancara dengan peserta, Bandicam lebih banyak digunakan karena proses menyimpan video dalam format MP4 membutuhkan waktu yang sangat singkat dibandingkan dengan Screen O-Matic, kualitas video yang dihasilkan juga lebih baik, ukuran filenya lebih kecil sehingga menghemat ruang penyimpanan dan mudah untuk dipublikasi pada akun youtube atau dikirim lewat WhatssApp. Sedangkan peserta memilih menggunakan aplikasi Screen O-Matic karena aplikasi ini saja yang dapat diinstal pada laptop mereka sedangkan aplikasi Bandicam tidak bisa diinstal pada laptopnya dan peserta yang memilih menggunakan kedua aplikasi tersebut dengan alasan ingin latihan dan untuk melihat perbedaan penggunaan kedua aplikasi tersebut.

Peserta terlihat sangat antusias dalam tahap kegiatan ini. Hal ini terlihat dari jumlah peserta yang aktif membuat video pembelajaran. Peserta berpendapat bahwa pembuatan video pembelajaran ini merupakan hal baru bagi mereka, aplikasi yang digunakan untuk membuat video sangat mudah digunakan, tidak memerlukan alat perekaman yang banyak tapi hanya menggunakan laptop saja dan video yang dihasilkan dapat langsung diberikan kepada siswa untuk digunakan. Walaupun masih ada kendala-kendala yang dihadapi saat pembuatan video. Kendala yang dihadapi oleh peserta saat pembuatan video antara lain:

1) Pembuatan video membutuhkan waktu yang lama. Hal ini disebabkan karena pembuatan video ini merupakan hal baru bagi peserta. Seringkali perekaman video harus dilakukan berulang-ulang kali karena masalah teknis saat perekaman, saat dipertengahan peserta lupa akan hal-hal yang ingin disampaikan sehingga terhenti dan ada juga peserta yang memerlukan latihan berulang-ulang kali.

2) Pembuatan video membutuhkan waktu dan ruang khusus. Karena saat perekaman butuh ruangan yang tidak terganggu oleh siapapun atau terhindar dari suara bising maka peserta perlu menentukan waktu yang tepat untuk melakukan perekaman agar bisa fokus dan menghasilkan kualitas suaran yang baik. 
3) Perangkat kamera dan perekam suara pada laptop yang terganggu mempengaruhi hasil perekaman.

4) Media presentasi powerpoint yang disiapkan belum lengkap maka proses rekam video harus dihentikan sementara untuk memperbaiki kualitas powerpoint. Setelah bahan presentasi dirasa sudah lengkap baru kembali melakukan perekaman

5) Bila terjadi kesalahan saat perekaman, peserta harus mengulang kembali proses merekam video dari awal karena peserta belum diajarkan cara mengedit video menggunakan aplikasi editing video.

Selanjutnya, video yang dihasilkan dikirim ke tim pengabdian untuk dievaluasi lebih lanjut.

4) Evaluasi dan Revisi video pembelajaran

Peserta diminta mengirim satu video yang telah dibuat dalam bentuk link kepada tim pengabdian lewat grup WhatsApp untuk dievaluasi. Instrumen yan digunakan untuk mengevaluasi video pembelajaran yang dirancang oleh peserta terdiri diadaptasi dari instrumen evaluasi media pembelajaran yang dirancang oleh Chaeruman, Uwes (2015) dengan memperhatikan 1) aspek materi, 2) aspek desain pembelajaran dan 3) aspek media dan komunikasi pembelajaran. Indikator dari tiap-tiap aspek disajikan pada tabel berikut.

Tabel 1. Indikator Penilaian Video Pembelajaran

\begin{tabular}{|ll|}
\hline \multicolumn{1}{|c|}{ A. Materi } \\
\hline $\begin{array}{l}\text { 1. Kebenaran isi materi } \\
\text { 2. Kecakupan dan Kecukupan materi }\end{array}$ \\
\hline \multicolumn{1}{c|}{ B. Desain Pembelajaran } \\
\hline $\begin{array}{l}\text { 1. Ketepatan strategi penyampaian sehingga memungkinkan kemudahan dan } \\
\text { kecepatan pemahaman dan penguasaan materi, konsep atau keterampilan }\end{array}$ \\
2. Tingkat kemungkinan mendorong kemampuan siswa berpikir kritis dan \\
memecahkan masalah
\end{tabular}

Berdasarkan indikator-indikator evaluasi video pembelajaran yang dijabarkan pada tabel di atas, tim pengabdian memberikan penilaian dan meminta peserta memperbaiki video yang telah dibuat berdasarkan catatan-catatan dari tim pengabdian. Video-video yang telah direvisi diupload ke akun youtube masingmasing atau disimpan pada komputer masing-masing untuk dipakai dalam kegiatan 
pembelajaran dalam jaringan. Produk yang dihasilkan dalam bentuk video pembelajaran merupakan suatu produk yang memiliki manfaat berkelanjutan dan dapat digunakan untuk menjangkau semua komponen yang membutuhkan dan berdampak positif bagi siswa (Kisa \& Stein, 2017). Pembuatan video pembelajaran ini merupakan rangkaian aktifitas yang perlu dipelajari oleh guru sebagai tindakan menghadapi transformasi dalam dunia pendidikan dan untuk melakukan reformasi tujuan pembelajaran di kelas. Oleh karena itu, menurut Easterbrook, Stephenson dan Mertens (2006) guru perlu secara konsistensi dengan upaya-upaya ini dalam merencanakan dan mengembangkan video-video pembelajaran secara profesional.

Temuan-temuan menarik dari tahapan kegiatan ini antaralain :

1) Terdapat peserta yang menggunakan pendekatan kebudayaan dalam proses pembelajaran

2) Terdapat peserta yang membuat video pembelajaran sebagai media interatif yang menarik

Selain temuan menarik di atas, adapun kesulitan-kesulitan peserta dalam menyusun konten dalam video pembelajaran antaralain:

1) Untuk mata pelajaran matematika guru sulit menyajikan materi dalam masalahmasalah kontekstual

2) Guru sulit menentukan ilustrasi-ilustrasi yang sesuai dengan kondisi siswa. Dalam membuat ilustrasi guru lebih banyak mengadopsi ilustrasi dalam bukubuku pelajaran, atau sumber-sumber belajar yang tersedia di internet

3) Pada umumnya, penyajian materi dilakukan dengan metode ceramah tanpa mengutamakan proses berpikir kritis siswa.

3. Evaluasi Pelaksanaan Kegiatan

a. Kelemahan-kelemahan

Kelemahan-kelemahan yang ditemukan dari kegiatan pelatihan video pembelajaran menggunakan Bandicam dan Screen O-Matic ini antaralain:

Peserta tidak dibekali cara mengedit video-video hasil perekaman sehingga proses perekaman dilakukan berkali-kali. Hal ini mengakibatkan peserta membutuhkan waktu yang lebih lama untuk menghasilkan satu video pembelajaran

1) Kegiatan dalam jaringan yang selalu mengandalkan jaringan internet mengakibatkan proses kegiatan sering terputus atau peserta sulit berkomunikasi dengan tim pengabdian

2) Peserta pada awal kegiatan yakni pada kegiatan webinar berjumlah 90 orang. Namun jumlah ini makin berkurang ketika kegiatan dilanjutkan dalam kegiatan pendampingan pembuatan video pembelajaran. Sampai pada tahap kedua hanya tersisa 53 peserta yang aktif sampai menghasilkan video pembelajaran

3) Evaluasi terhadap video pembelajaran tidak dilakukan secara mendalam dengan melakukan perhitungan-perhitungan kuantitatif. Penilaian yang diberikan menurut panduan instrumen hanya dilakukan secara kualitatif untuk melihat hal-hal yang tidak sesuai dengan harapan untuk diperbaiki oleh peserta.

4) Tidak dilakukan evaluasi terkait penggunaan video yang dihasilkan peserta di kelas masing-masing.

b. Kelebihan-kelebihan

Kelebihan yang merupakan maanfaat yang diterima langsung oleh peserta dan tim pengabdian antaralain

1) Selain peserta mendapatkan pengetahuan dan pengalaman menarik dalam membuat video pembelajaran menggunakan aplikasi Bandicam dan Screen O- 
Matic, peserta juga belajar membuat materi presentasi dengan menggunakan powerpoint

2) Tim pengabdian mendapatkan gambaran-gambaran umum terkait kemampuan guru-guru yang tersebar di seluruh wilayah Nusa Tenggara Timur terkait dengan kemampaun pelaksanaan pembelajaran secara daring di masing-masing daerah bahkan daerah $3 \mathrm{~T}$ serta kemampuan guru-guru memanfaatkan teknologi dalam pembelajaran di kelas. Hal ini menjadi masukan bagi tim pengabdian untuk melakukan kegiatan pengabdian dan penelitian lanjutan berdasarkan masukanmasukan tersebut.

\section{Kesimpulan}

Berdasarkan hasil kegiatan dan pembahasan di atas maka dapat disimpulkan bahwa:

a. Hasil dari kegiatan pelatihan pembuatan video pembelajaran dengan menggunakan Bandicam dan Screen O-Matic yaitu dapat meningkatkan pengetahuan guru-guru tentang pemanfaatan aplikasi-aplikasi tersebut, mengenal fitur-fitur aplikasi dalam membuat video pembelajaran, kelemahan dan kelebihan dari tiap aplikasi dan pengetahuan tentang tahap-tahap pembuatan video pembelajaran.

b. Hasil dari kegiatan pendampingan pembuatan video pembelajaran dengan menggunakan aplikasi Bandicam dan Screen O-Matic yaitu dapat meningkatkan keterampilan guru-guru dalam membuat video pembelajaran dengan menggunakan Bandicam dan/atau Screen OMatic. Hal ini ditandai dengan adanya video-video pembelajaran yang dibuat oleh guru dengan menggunakan aplikasi tersebut.

c. Hasil lainnya dari kegiatan ini adalah meningkatnya keterampilan guru-guru dalam menggunakan powerpoint untuk membuat bahan presentasi dan media pembelajaran terutama dalam hal mengemas presentasi yang menarik dengan memperhatikan keserasian warna, tata letak gambar, tata letak huruf, warna latar, warna huruf, membuat animasi sesuai tema, menggunakan gambar. Icon, ilustrasi gambar dan lain-lain. Peserta juga mendapatkan pengetahuan tambahan terkait menyusun konten, menentukan urutan materi dan menetapkan point-point penting dalam sebuah presentasi.

d. Berdasarkan kelemahan dan kelebihan yang telah dijelaskan maka diperlukan pelatihanpelatihan untuk meningkatkan pengetahuan dan keterampilan guru-guru dalam mengembangkan pelajaran dalam jaringan berbasis E-Learning, pelatihan mengembangkan media pembelajaran interaktif berbasis IT, dan pelatihan pengembangan perangkat pembelajaran dalam jaringan. Selain itu, model pelatihan dan metode kegiatan perlu dikembangkan lebih baik dengan memperhatikan kondisi guru-guru di lapangan dan dievaluasi secara ilmiah untuk menguji tingkat keberhasilan dari setiap metode/model pelatihan.

\section{Daftar Pustaka}

Chaeruman, Uwes. Anis. (2015). Instrumen Evaluasi Media Pembelajaran. Pusat Teknologi Informasi dan Komunikasi Pendidikan Kementerian Pendidikan dan Kebudayaan.

Easterbrooks, Susan R., Stephenson, Brenda., Mertens, Donna M. (2006). Master teachers' responses to twenty literacy and science mathematics practices in deaf education. Jurnal American Annals of the Deaf, 151(4), 398 - 409, https://muse.jhu.edu/article/206635

Hadiyanti, Widi. K. M dan Widya. (2018). Analyzing the values and effects of powerpoint presentations. LTT Journal: A journal on Language dan Language Teaching, 21(1), 87-95. 
Herayanti, Lovy., Safitri, Rina Baiq., Sukroyanti, Baiq Azmi., Putrayadi, Wirawan. (2019). Pelatihan pembuatan video pembelajaran bagi guru-guru di sdn 1 ubung dengan memanfaatkan bandicam. Jurnal Pendidikan dan Pengabdian Masyarakat, 2(4), 495-501. https://academicworks.cuny.edu/cgi/viewcontent.cgi?article=1244\&context=le_pubs

Kisa-Tekkumru, Miray dan Stein, Kay Mary. (2017). Designing, facilitating, and scaling-up video-based professional development: supporting complex forms of teaching in science and mathematics. International Journal of STEM Education, 4(1), 1-9, https://www.ncbi.nlm.nih.gov/pmc/articles/PMC6310378/

Jones, M Allan. (2003). The use and abuse of powerpoint in teaching and learning in the life sciences: A personal overview. Bioscience Education, 2(1), 1-13 https://www.tandfonline.com/doi/full/10.3108/beej.2003.02000004.

Lari, Samiei Fateme. (2014). The impact of using powerpoint presentations on students' learning and motivation in secondary schools. Procedia - Social and Behavioral Sciences. 98, 1672-1677, https://www.sciencedirect.com/science/article/pii/S1877042814026834.

Marlena, N., Dwijayanti, R., Patrikha, F. D., Parjono, P., \& Sudarwanto, T. (2018). Penyegaran kemampuan guru dalam merancang media pembelajaran melalui aplikasi powtoon dan screencast o matic. Jurnal Pemberdayaan Masyarakat Madani (JPMM), 2(2), 204-223, http://journal.unj.ac.id/unj/index.php/jpm/article/view/8621

Muhasim. (2017). Pengaruh tehnologi digital terhadap prestasi belajar siswa. Palapa: Jurnal Jurnal Studi Keislaman dan Ilmu Pendidikan, 5(2), 53-77.

Palobo, Markus \& Tembang, Yonarlianto. (2019). Analisis kesulitan guru dalam implementasi kurikulum 2013 di Kota Merauke. Sebatik, 2(2), 307-316 https://jurnal.wicida.ac.id/index.php/sebatik/article/view/775.

Salsabila, Hanifa Unik., Sari, Irna Laili., Latif, Haibati Khusna., Lestari, Puji Ayu., Ayuning, Asyharinur . (2020). Peran teknologi dalam pembelajaran di masa pandemi covid-19. AlMutharahah: Jurnal Penelitian dan Kajian Sosial Keagamaan, 17(2), 188-198, https://ojs.diniyah.ac.id/index.php/Al-Mutharahah/article/view/138.

Shigli, Kamal., Agrawal., Nair, Chandrasekharan., Sajjan, Suresh., Kakodkar, Pradnya, dan Hebbal, Mamata Hebbal. (2019). Use of powerPoint presentation as a teaching tool for undergraduate students in the subject of gerodontology. The Journal of Indian Proshodontic Society, 16(2), 187-192, https://www.ncbi.nlm.nih.gov/pmc/articles/PMC4837778/. 